\title{
Factors associated with improvement in frailty status defined using the frailty phenotype: A systematic review and meta-analysis
}

Gotaro Kojima, $\mathrm{MD}^{1,2}$; Yu Taniguchi, $\mathrm{PhD}^{3}$; Steve Iliffe, FRCGP ${ }^{1}$; Tomohiko Urano, $\mathrm{MD}, \mathrm{PhD}^{4}$; Kate Walters, $\mathrm{PhD}^{1}$.

1 Department of Primary Care and Population Health, University College London, London, $\mathrm{UK}$

2 Videbimus Toranomon Clinic, Tokyo, Japan

3 Center for Health and Environmental Risk Research, National Institute for Environmental Studies, Tsukuba, Japan

4 Department of Geriatric Medicine, International University of Health and Welfare, Chiba, Japan.

Corresponding Author:

Gotaro Kojima, MD

Department of Primary Care and Population Health

University College London (Royal Free Campus)

Rowland Hill Street,

London, NW3 2PF, UK

Phone: +44 (0)20 77940500

Fax: +44 (0)20 74726871

Email: gotarokojima@yahoo.co.jp

To the editor:

Frailty is a state characterized by decreased reserve across multiple physiological systems due to aged-related cumulative deficits. ${ }^{1}$ Once frailty has developed, it often leads to a downward spiral in overall health. ${ }^{1}$ However frailty is not necessarily an irreversible process but a dynamic continuum state that can both worsen and improve over time. ${ }^{2}$ Although numerous previous studies have examined various factors associated with increased frailty risks, ${ }^{3}$ little is known regarding frailty status improvement and related factors and, there is no systematic review and meta-analysis found in the literature. We therefore performed a systematic review of the literature for currently available evidence on factors associated with improvement in frailty status defined using the frailty phenotype and conducted a meta-analysis to pool the results.

\section{Methods}

A systematic review of the literature was conducted in October 2018 based on a protocol developed a priori in accordance with the PRISMA statements. ${ }^{4}$ The protocol was registered at PROSPERO (CRD42018109305). Briefly, any prospective cohort studies examining factors associated with improvement of frailty status based on three categories defined by Fried frailty phenotype criteria (robust, prefrailty and frailty) among community-dwelling older people with a mean age of 60 or more. Please see Appendix 1 for detail.

\section{Results}

Among 11,600 studies identified by the systematic literature search and 5 studies found from other sources, 13 studies with a cumulative total of 53,679 participants to be included in this review and are summarized in Appendix 2. All the included studies were considered to have adequate methodological quality based on the Newcastle-Ottawa scale. 
Among 6 studies with 28,608 participants, age, ${ }^{5,6}$ gender, ${ }^{5,7-9}$ smoking status, ${ }^{5,6,9,10}$ diabetes, ${ }^{5,10}$ stroke, ${ }^{5,10}$ chronic obstructive pulmonary disease (COPD) ${ }^{5,10}$ and cancer ${ }^{5,10}$ were examined as a predictor of frailty status improvement in three or more cohorts and were used for a meta-analysis. Fixed-effects meta-analyses were conducted as no significant heterogeneity was observed for these factors $\left(\mathrm{p} \geq 0.08, \mathrm{I}^{2}=0-60 \%\right)$, except for male gender $\left(\mathrm{p}<0.01, \mathrm{I}^{2}=90 \%\right)$, where a random-effect meta-analysis was used. Younger age, never smoking, no history of diabetes, stroke, and COPD, respectively, predicted significantly higher chances of improving frailty status, while there were no significant associations of gender and history of cancer with frailty improvement (Figure 1). Although there were various other factors examined within studies, a meta-analysis was not possible due to different methodologies or the range of factors were used in one or two cohorts. (Appendix 2)

\section{Discussion}

Among the factors used in the meta-analyses, younger age, never smoking, no history of diabetes, stroke and COPD, respectively, predicted significantly higher chances of improving frailty status. Such findings are expected given that these factors are counterparts of risk factors of incident frailty. However, some factors known to be associated with frailty risk, such as female gender or cancer, did not have significant effects on frailty improvement.

Better characterization of factors associated with frailty improvement would further enhance our understanding of frailty transition mechanisms and provide useful information for risk stratification of older people.

\section{Clinical implications:}

Attention to factors that increase risk of co-morbidities (including smoking cessation) may be a way to improve frailty status and can be considered as a part of frailty interventions. Frailty is a dynamic state and can improve: a better understanding of those who are more likely to improve is beneficial in informing prognosis and advanced care planning decisions.

\section{Limitations}

Due to different methodologies and statistical approaches and the limited number of the studies, a meta-analysis was not possible for all factors. Among the studies included in the meta-analyses, not all studies adjusted for important confounders of frailty, such as age, gender, smoking, alcohol, wealth and education. Lastly, because the current review included only studies using Fried frailty phenotype criteria our findings may not be applicable to that based on other frailty tools.

\section{Conclusions and Implications}

The current systematic review and meta-analysis demonstrates pooled evidence that younger age, never smoking, no history of diabetes, stroke or COPD, respectively, are significantly associated with higher chances of improvement in frailty among community-dwelling older people. The number of studies examining frailty improvement is much fewer than that of studies examining frailty risk or incidence. More studies are needed on factors associated with frailty improvement, especially modifiable ones so that tailored interventions can be targeted in order to potentially improve frailty status.

Funding sources: This study was supported by the Sasakawa Foundation grant (Grant Application No. 5364). GK is funded by a University College London (UCL) Overseas 
Research Scholarship. Neither funder had any influence on the study design and collection, analysis and interpretation of data, writing the manuscript and the decision to submit it for publication.

\section{Conflicts of interest}

None.

\section{REFERENCES}

1. Clegg, A, Young, J, Iliffe, S, et al. Frailty in elderly people. Lancet (London, England) 2013;381(9868):752-762.

2. Kojima, G, Taniguchi, Y, Iliffe, S, et al. Transitions between frailty states among community-dwelling older people: A systematic review and meta-analysis. Ageing research reviews 2019;50:81-88.

3. Feng, Z, Lugtenberg, M, Franse, C, et al. Risk factors and protective factors associated with incident or increase of frailty among community-dwelling older adults: A systematic review of longitudinal studies. PloS one 2017;12(6):e0178383.

4. Moher, D, Liberati, A, Tetzlaff, J, et al. Preferred reporting items for systematic reviews and meta-analyses: the PRISMA statement. BMJ (Clinical research ed) 2009;339:b2535.

5. Lee, JS, Auyeung, TW, Leung, J, et al. Transitions in frailty states among communityliving older adults and their associated factors. Journal of the American Medical Directors Association 2014;15(4):281-286.

6. Trevisan, C, Veronese, N, Maggi, S, et al. Factors Influencing Transitions Between Frailty States in Elderly Adults: The Progetto Veneto Anziani Longitudinal Study. Journal of the American Geriatrics Society 2017;65(1):179-184.

7. Ahmad, NS, Hairi, NN, Said, MA, et al. Prevalence, transitions and factors predicting transition between frailty states among rural community-dwelling older adults in Malaysia. PloS one 2018;13(11):e0206445.

8. Borrat-Besson, C, Ryser, V-A, Wernli, B. 15 Transitions between frailty states-a European comparison, Active ageing

solidarity between generations in Europe: First results from SHARE after the economic crisis. 2013.

9. Thompson, MQ, Theou, O, Adams, RJ, et al. Frailty state transitions and associated factors in South Australian older adults. Geriatrics \& gerontology international 2018;18(11):1549-1555.

10. Pollack, LR, Litwack-Harrison, S, Cawthon, PM, et al. Patterns and Predictors of Frailty Transitions in Older Men: The Osteoporotic Fractures in Men Study. Journal of the American Geriatrics Society 2017;65(11):2473-2479. 
Figure 1. Forest plots of pooled odds ratios of improvement in frailty status using a fixedeffects meta-analysis. (A mixed-effects model was used for male gender.)

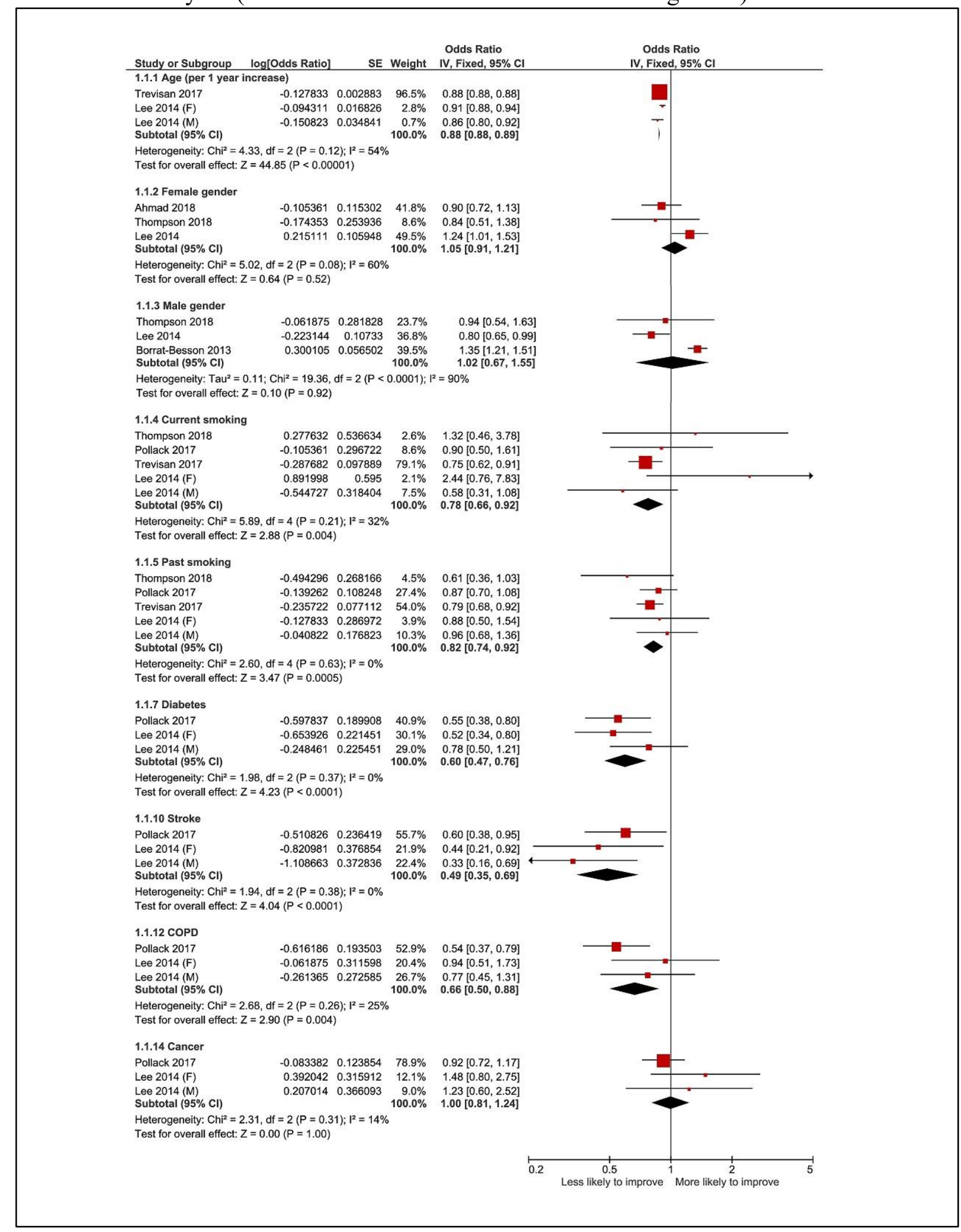




\section{Appendix 1. Methods}

\section{METHODS}

\section{Search strategy and study selection}

Five electronic databases: Embase, MEDLINE, CINAHL Plus, PsycINFO and AMED, were searched with an explosion function when available and without language restriction. Any prospective cohort studies that examined factors associated with improvement of frailty status based on three categories defined by CHS criteria, i.e. robust, prefrailty and frailty, were eligible. $^{2}$ In this review only studies using CHS criteria were considered in order to collect consistent evidence based on the same frailty definition. The search period was between 2000 and 2018 as CHS criteria was published in $2001 .^{2}$ A combination of Medical Subject Heading $(\mathrm{MeSH})$ and free text terms was used as follows: "transition*" OR "improv*" OR "course" OR "progression*" AND Frailty (MeSH) OR "frailty" OR Frail Elderly (MeSH) OR "Frailty Syndrome (MeSH)". The reference lists of the relevant articles and the included articles were reviewed for additional studies. The forward citation tracking of the included studies was also conducted using Google scholar (https://scholar.google.com).

Studies were considered potentially eligible if they prospectively examined associations between factors at baseline or during the follow-up and subsequent improvement in frailty status among community-dwelling older people with a mean age of 60 and older. An improvement in frailty status was defined as a change from one of three frailty phenotype type criteria (robust, prefrail and frail) to another one that is less frail, specifically either from frail to prefrail, frail to robust or prefrail to robust. Randomised controlled trials, editorials, reviews or conference abstracts were not considered. Studies were excluded if they used selected cohorts with specific diseases or conditions, such as patients with cancers or hospitalised patients.

Titles, abstracts and full-texts of the studies identified through the systematic review were independently screened and evaluated for eligibility by two researchers (GK and YT). Any disagreement was solved by discussion.

\section{Data Extraction}

Data extracted from each eligible study included first author, cohort name if any, publication year, location, sample size, proportion of female participants, mean age, age range, follow-up period and findings including factors of interest and covariates used for adjustment.

\section{Methodological Quality Assessment}

Each of studies that were considered as eligible was examined for methodological quality using the Newcastle-Ottawa scale for cohort studies, which consists of 9 items covering three domains (selection, comparability and outcome). For this review, one of the criteria for outcome, 'Demonstration that outcome of interest was not present at start of study' was not applicable as the outcome of interest was improvement of frailty status. Therefore, the remainder of 8 items were used and a study that met four items or more was considered to have adequate methodological quality. The studies were not excluded based on the scores.

\section{Statistical Analysis}

When three or more studies examined the same variable as a predictor of subsequent improvement in frailty status and provided the effect measures, such as odds ratio (OR) or hazard ratio (HR), the results were pooled by a meta-analysis with the inverse variance method. Heterogeneity across the studies was examined using chi-square test and its degree 
was quantified using $\mathrm{I}^{2}$ statistic. If a significant heterogeneity was detected, a random-effects meta-analysis was performed, and if not, a fixed-effects meta-analysis was chosen. When unadjusted and adjusted effect measures were presented, the most adjusted ones were chosen. When a study provided results based on male and female cohorts, each cohort was included in the meta-analysis separately. Some studies calculated effect measures based on baseline frailty status, these effect measures were first combined using a fixed-effects meta-analysis, and were entered into the main meta-analysis. If only either one effect measure among the prefrail at baseline or the frail at baseline was shown, the available one was included in the meta-analysis. Publication bias was visually examined a funnel plot. If significant heterogeneity was identified, subgroup and sensitivity meta-analyses were used to explore potential causes. All analyses were conducted using Review Manager 5 (Version 5.2, The Cochrane Collaboration, Copenhagen, Denmark), and two-sided p value of less than 0.05 was considered as statistically significant.

\section{REFERENCES}

1. Moher, D, Liberati, A, Tetzlaff, J, et al. Preferred reporting items for systematic reviews and meta-analyses: the PRISMA statement. BMJ (Clinical research ed) 2009;339:b2535.

2. Fried, LP, Tangen, CM, Walston, J, et al. Frailty in older adults: evidence for a phenotype. The journals of gerontology Series A, Biological sciences and medical sciences 2001;56(3):M146-156. 
Appendix 2. Summary of the studies examining improvement in frailty status among community-dwelling older people.

\begin{tabular}{|c|c|c|c|c|c|c|}
\hline $\begin{array}{l}\text { First author/Year } \\
\text { Study }\end{array}$ & Location & $\begin{array}{l}\text { Sample } \\
\text { size }\end{array}$ & $\begin{array}{c}\text { Female } \\
(\%)\end{array}$ & $\begin{array}{c}\text { Age } \\
\text { (range) }\end{array}$ & $\begin{array}{l}\text { Follow-up } \\
\text { period }\end{array}$ & Factors \\
\hline Ahmad $2018^{1}$ & Malaysia & 2,324 & $62.1 \%$ & $(\geq 60)$ & 1 year & $\begin{array}{l}\text { Age, gender, cognition, physical activity } \\
\text { level }\end{array}$ \\
\hline $\begin{array}{l}\text { Swiecicka } 2018^{2} \\
\text { EMAS }\end{array}$ & $\begin{array}{l}8 \text { European } \\
\text { countries* }\end{array}$ & 3,369 & $0 \%$ & $(40-79)$ & 4.3 years & $\begin{array}{l}\text { Dihydrotestosterone, estradiol, follicle- } \\
\text { stimulating hormone, free testosterone } \\
\text {-luteinizing hormone, sex hormone- } \\
\text { binding globulin, total testosterone }\end{array}$ \\
\hline $\begin{array}{l}\text { Thompson } 2018^{3} \\
\text { North West Adelaide } \\
\text { Health Study }\end{array}$ & Australia & 696 & $53.1 \%$ & $\begin{array}{l}73.4 \\
(\geq 65)\end{array}$ & 4.5 years & $\begin{array}{l}\text { Age, gender, smoking, alcohol, SES, } \\
\text { education, obesity, polypharmacy, } \\
\text { multimorbidity, living alone }\end{array}$ \\
\hline $\begin{array}{l}\text { Wei } 2018^{4} \\
\text { SLAS-2 }\end{array}$ & Singapore & 1,162 & $63.6 \%$ & $\begin{array}{c}65.3 \\
(>55)\end{array}$ & 5 years & Nutritional status \\
\hline $\begin{array}{l}\text { Yu } 2018^{5} \\
\text { Mr. and Ms. OS }\end{array}$ & China & 3,240 & $49.2 \%$ & $\begin{array}{l}72.2 \\
(>65)\end{array}$ & 2 years & Neighborhood green space \\
\hline $\begin{array}{l}\text { Pollack } 2017^{6} \\
\text { MrOS study }\end{array}$ & US & 5,086 & $0 \%$ & $\begin{array}{l}73.4 \\
(\geq 65)\end{array}$ & 4.6 years & $\begin{array}{l}\text { SES, education, smoking, alcohol, } \\
\text { ethnicity, marital status, IADL, self- } \\
\text { reported health, leg power, able to } \\
\text { complete chair stand, number of } \\
\text { comorbidities, cognition, cancer, COPD, } \\
\text { CHF, DM, HTN, osteoporosis, stroke, } \\
\text { albumin, creatinine, CRP, glucose, IL-6, } \\
\text { TNF- } \alpha\end{array}$ \\
\hline $\begin{array}{l}\text { Trevisan } 2017^{7} \\
\text { Pro. V.A. }\end{array}$ & Italy & 2,925 & $63.3 \%$ & $\begin{array}{l}74.4 \\
(\geq 65)\end{array}$ & 4.4 years & $\begin{array}{l}\text { Age, gender, income, education, } \\
\text { smoking, alcohol, marital status, living } \\
\text { alone, ADL disability, IADL disability, } \\
\text { weight, physical function, number of } \\
\text { medications, cognition, vision loss, } \\
\text { anemia, cancer, cardiovascular disease, } \\
\text { DM, hyperuricemia, osteoarthritis, } \\
\text { vitamin D level }\end{array}$ \\
\hline $\begin{array}{l}\text { Jamsen } 2016^{8} \\
\text { CHAMP }\end{array}$ & Australia & 1,705 & $0 \%$ & $\begin{array}{c}76.0 \\
(\geq 70)\end{array}$ & 2 years & $\begin{array}{l}\text { Number of medications, the Drug } \\
\text { Burden Index }\end{array}$ \\
\hline $\begin{array}{l}\text { Alencar } 2015^{9} \\
\text { FIBRA }\end{array}$ & Brazil & 207 & $76.8 \%$ & $\begin{array}{l}78.4 \\
(>65)\end{array}$ & 1 year & $\begin{array}{l}\text { Cancer, Urinary incontinence, Advanced } \\
\text { ADL disability }\end{array}$ \\
\hline $\begin{array}{l}\text { Etman } 2015^{10} \\
\text { SHARE }\end{array}$ & $\begin{array}{l}11 \text { European } \\
\text { countries** }\end{array}$ & 14,082 & $54.3 \%$ & $(>55)$ & 2 years & Education \\
\hline Lee $2014^{11}$ & China & 3,018 & $49.7 \%$ & $\begin{array}{l}73.6 \\
(\geq 65)\end{array}$ & 2 years & $\begin{array}{l}\text { Age, SES, smoking, BMI, cognition, } \\
\text { hospitalisation, cancer, COPD, DM, } \\
\text { heart disease, hip fracture, osteoarthritis, } \\
\text { stroke }\end{array}$ \\
\hline $\begin{array}{l}\text { Borrat-Besson } 2013^{12} \\
\text { SHARE }\end{array}$ & $\begin{array}{l}12 \text { European } \\
\text { countries } * * *\end{array}$ & 15,127 & $54.1 \%$ & $\begin{array}{c}63.9 \\
(>50)\end{array}$ & 4 years & $\begin{array}{l}\text { Gender, living alone, regular physical } \\
\text { exercise, country }\end{array}$ \\
\hline $\begin{array}{l}\text { Gill } 2011^{13} \\
\text { Precipitating Events } \\
\text { Project }\end{array}$ & US & 738 & $64.5 \%$ & $\begin{array}{l}78.4 \\
(\geq 70)\end{array}$ & 9 years & Hospitalisation \\
\hline
\end{tabular}

* Belgium, Estonia, Hungary, Italy, Poland, Spain, Sweden, the UK.

Spain, Sweden, Switzerland

** Austria, Belgium, Denmark, France, Germany, Greece, Italy, the Netherlands, Spain,

Sweden, Switzerland.

*** Austria, Belgium, Czechia, Denmark, France, Germany, the Netherlands, Italy, Poland,

ADL: Activities of daily living

CHAMP: Concord Health and Ageing in Men Project

CHF: Congestive heart failure

COPD: Chronic obstructive pulmonary disease 
CRP: C-reactive protein

DM: Diabetes mellitus

EMAS: European Male Ageing Study

FIBRA: Rede de Estudos da Fragilidade de Idosos Brasileiros

HTN: Hypertension

IADL: Instrumental activities of daily living

IL-6: Interleukin-6

MCS: Mental component score

PCS: Physical component score

Pro. V.A.: Progetto Veneto Anziani study

SES: Socioeconomic status

SLAS-2: Singapore Longitudinal Ageing Study 2

TNF- $\alpha$ : Tumour necrosis factor- $\alpha$

\section{References}

1. Ahmad, NS, Hairi, NN, Said, MA, et al. Prevalence, transitions and factors predicting transition between frailty states among rural community-dwelling older adults in Malaysia. PloS one 2018;13(11):e0206445.

2. Swiecicka, A, Eendebak, R, Lunt, M, et al. Reproductive Hormone Levels Predict Changes in Frailty Status in Community-Dwelling Older Men: European Male Ageing Study Prospective Data. The Journal of clinical endocrinology and metabolism 2018;103(2):701-709.

3. Thompson, MQ, Theou, O, Adams, RJ, et al. Frailty state transitions and associated factors in South Australian older adults. Geriatrics \& gerontology international 2018;18(11):1549-1555.

4. Wei, K, Thein, FS, Nyunt, MSZ, et al. Nutritional and Frailty State Transitions in the Singapore Longitudinal Aging Study. The journal of nutrition, health \& aging 2018;22(10):1221-1227.

5. Yu, R, Wang, D, Leung, J, et al. Is Neighborhood Green Space Associated With Less Frailty? Evidence From the Mr. and Ms. Os (Hong Kong) Study. Journal of the American Medical Directors Association 2018;19(6):528-534.

6. Pollack, LR, Litwack-Harrison, S, Cawthon, PM, et al. Patterns and Predictors of Frailty Transitions in Older Men: The Osteoporotic Fractures in Men Study. Journal of the American Geriatrics Society 2017;65(11):2473-2479.

7. Trevisan, C, Veronese, N, Maggi, S, et al. Factors Influencing Transitions Between Frailty States in Elderly Adults: The Progetto Veneto Anziani Longitudinal Study. Journal of the American Geriatrics Society 2017;65(1):179-184.

8. Jamsen, KM, Bell, JS, Hilmer, SN, et al. Effects of Changes in Number of Medications and Drug Burden Index Exposure on Transitions Between Frailty States and Death: The Concord Health and Ageing in Men Project Cohort Study. Journal of the American Geriatrics Society 2016;64(1):89-95.

9. Alencar, MA, Dias, JMD, Figueiredo, LC, et al. Transitions in frailty status in community-dwelling older adults. 2015;31(2):105-112.

10. Etman, A, Kamphuis, CB, van der Cammen, TJ, et al. Do lifestyle, health and social participation mediate educational inequalities in frailty worsening? European journal of public health 2015;25(2):345-350. 
11. Lee, JS, Auyeung, TW, Leung, J, et al. Transitions in frailty states among communityliving older adults and their associated factors. Journal of the American Medical Directors Association 2014;15(4):281-286.

12. Borrat-Besson, C, Ryser, V-A, Wernli, B. 15 Transitions between frailty states-a European comparison, Active ageing

solidarity between generations in Europe: First results from SHARE after the economic crisis. 2013.

13. Gill, TM, Gahbauer, EA, Han, L, et al. The relationship between intervening hospitalizations and transitions between frailty states. The journals of gerontology Series A, Biological sciences and medical sciences 2011;66(11):1238-1243. 